\title{
The Impact of Real Exchange Rate Undervaluation on Economic Growth: Evidence from Panel Cointegration Approach
}

Mehdi Seraj ( $\nabla$ seraj.mehdi@gmail.com )

Near East University https://orcid.org/0000-0002-4746-6970

Cagay Coskuner

Dogu Akdeniz Universitesi

Seyi Saint Akadiri

Dogu Akdeniz Universitesi

Negar Bahadori

Dogu Akdeniz Universitesi

\section{Research}

Keywords: Real exchange rate, economic growth, developed economies, developing economies, panel cointegration approach

Posted Date: March 11th, 2020

DOl: https://doi.org/10.21203/rs.3.rs-16924/v1

License: (c) (i) This work is licensed under a Creative Commons Attribution 4.0 International License. Read Full License 


\title{
The Impact of Real Exchange Rate Undervaluation on Economic Growth: Evidence from Panel Cointegration Approach
}

\author{
Mehdi Seraj*, Cagay Coskuner, Seyi Saint Akadiri, Negar Bahadori
}

\begin{abstract}
This study revisited Dani Rodrik (2008) work on real exchange rate undervaluation and economic growth by using the Fully Modified Ordinary Least Square (FMOLS) and Dynamic Ordinary Least Square (DOLS). This research, to the best of authors' knowledge, is the first to use FMOLS and DOLS approach to empirically evaluate Rodrik work on the real exchange rate and economic growth using a Panel periodic data (six sets of five years) of 82 countries throughout 1990 to 2018. We used the Balassa Samuelson method to estimate the predicted real exchange rate and real exchange rate undervaluation. Finally, the study is in support of Rodrik conclusion that, real exchange undervaluation has a significant impact on the economic growth of the developing economies and statistically insignificant in the developed economies.

Keywords: Real exchange rate, economic growth, developed economies, developing economies, panel cointegration approach
\end{abstract}

JEL classification: C33, F43, O47 


\section{Introduction}

This case study intends to look at the effects of RER undervaluation on GDP growth and to identify if these effects vary with the level of economic development of the countries. For this purpose, the study uses a framework presented by Rodrik (2008) but also employs newer econometric methodologies to check the validity of the conclusion of Rodrik and to improve on that paper.

Recent studies have found a positive relation between RER undervaluation and GDP growth. As pointed out by Dani Rodrik (2008), RER is essential for GDP growth and the growth-enhancing the effect of real exchange rate undervaluation is found in developing countries.

Previous studies have employed several econometric models to analyze the impact of RER on GDP growth, but to the best of the author's knowledge, only a few studies have used the FMOLS and DOLS techniques in investigating the relationship between the RER undervaluation and economic growth.

This study uses panel data of 82 countries from 1990 to 2018. The data is periodic data with six sets of 5year-periods. The study investigates the effects of currency undervaluation on growth for developed and developing countries separately as well as a combined set. As mentioned earlier, the novelty of this study is its use of newer econometric methodologies in estimation. More specifically, the study uses Fully Modified Ordinary Least Square (FMOLS) and Dynamic Ordinary Least Square (DOLS) panel estimation techniques to confirm and to improve on the results of Rodrik (2008).

\section{Past Studies Review}

Rodrik (2008) mention that, overvaluation is harmful to growth, but undervaluation smoothens it. He argues that undervaluation of the currency is one of the most robust factors that appear to be supported strongly by cross country statistical evidence. Undervaluation is associated with high economic growth, and this effect holds on developing countries by a highly significant level and disappears for developed countries. He claims that undervaluation has a positive effect on the tradable sector, and especially industrial economic activities, hence countries that move toward tradable production, grow rapidly. According to Haddad, M., and Pancaro, C. (2010) managed real undervaluation can increase the domestic competitiveness to export and have more share of export. A stable real exchange rate undervaluation is a key factor of economic growth and works only for developing countries in the medium term because the real exchange rate in these countries determined by economic policies rather than by market fluctuations. If a policy cause to higher saving relative to investment, lead to real exchange rate depreciation. Although the undervaluation of the exchange rate is important but is not sufficient. 
Béreau, S., Villavicencio, A. L., \& Mignon, V. (2012) show that undervaluation increases economic growth significantly. Undervaluation encourages exports and promotes growth, but the growth depends on the size of undervaluation. Although Magud, N., \& Sosa, S. (2013) claim that foreign exchange rate inflows appreciate the real exchange rate, decrease the export and growth, Elbadawi, I., Kaltani, L., \& Soto, R. (2011) show that undervaluation is okay factor for sustained growth and depreciation, first of all, raises the export by increasing the profitability of the productive private sectors and raising the quality of exportable goods in market, and secondly, raises the cost of imported goods. Mejía-Reyes, P., Osborn, D. R., and Sensier, M. (2010) mention that undervaluation acts as a regime in economic growth and has a positive effect. Hence, the sign of the changing of the real exchange rate is a key factor in growth. Gala, P. (2007) argues that a currency undervaluation is a key factor in the development and according to Keynesian theorem undervaluation promote the exports, hence increase the employment and investment and also encourage the all sectors of industry to produce more to export by improving the level of technology in developing countries. In the same vein, Korinek, A., \& Servén, L. (2010) found that the balance of the real exchange rate can guarantee the macroeconomic balance during the midterm. Real undervaluation causes currency appreciation and inflation. Also Papanikos, G. T. (2015) found that an undervalued Euro cause to raises the economic growth, and Vaz, P. H., and Baer, W. (2014) argue that currency undervaluation has a positive effect on growth rate in the Latin American countries. The quality of this growth depends on the change in the real exchange rate strongly. Levy-Yeyati, E., \& Sturzenegger, F. (2007), Razmi, A., Rapetti, M., and Skott, P. (2012), and Mbaye, S. (2013) supported the Rodrik (2008) and found the same results.

According to Tang, B. (2015), the unstable currency has a negative effect on trade and economy. He shows that the depreciation of the exchange rate does not affect the Chinese economy. Also, Nouira, R., and Sekkat, K. (2012) discus that undervaluation cannot boost economic growth, but cause to high efficiency and higher growth. Undervaluation has a positive effect on export and a negative effect on other economic parts; hence, the effect on the economy may be negative. Finally, they could not show that depreciated RER increases economic growth. Gluzmann, P. A., Levy-Yeyati, E., \& Sturzenegger, F. (2012) discuss that Rodrik2008) ) found a positive relationship between the undervaluation on the industrial part, but they find the insignificant effect of undervaluation on the industry, negative on agriculture and positive on services.

Additionally, Das, D. K. (2009) argues that rich countries have a consumer price level higher than poor countries, and RER appreciation causes rapid economic growth. This finding was confirmed by RMB Yuan and China's growth and is different from the other searches and papers. Also, Cheung, Y. W., Chinn, M. D., \& Fujii, E. (2007) claim that there is not any evidence of RMB Yuan undervaluation in the economic growth of China because the exchange rate of China is not flexible and this policy avoids the shocks in the economy.

\section{Theoretical Background}

In this section, let us review some of the concepts related to real exchange rates and currency undervaluation.

\subsection{Real Exchange Rate}

Nominal exchange rates may have two different versions of definition: One definition is "the price of one foreign currency in terms of domestic currency" so that if the home country is assumed to be the USA, then the nominal exchange rate, for example, will be 1.3 USD for a British Pound. Let us denote this nominal exchange rate as $E_{d / f}$.

An alternative definition is "the amount of foreign currency we can buy with one unit of domestic currency" so that if the USA again is assumed to be the home country, then the nominal exchange rate, for example, will be 0.99 Swiss Franc for a USD. Let us denote this version of the nominal exchange rate as $E_{f / d}$.

Based on these two different versions of the nominal exchange rate, the real exchange rate (RER) can be calculated as; 


$$
\begin{array}{ll}
R E R=\frac{P_{d}}{E_{f / d} P_{f}} & \text { eq } 1 \\
R E R=\frac{E_{d / f} P_{f}}{P_{d}} & \text { eq } 2
\end{array}
$$

where $\mathrm{P}_{\mathrm{f}}$ and $\mathrm{P}_{\mathrm{d}}$ show the price levels in the foreign and home economy, respectively. Thus, the real exchange rates (RER) are the rates adjusted for different price levels in the two countries. As such, the RER in eq 1 measures the domestic prices relative to those in the foreign country while the RER in eq 2 measures the foreign prices relative to, or in comparison with, those inside the home country.

Since the nominal exchange rate $E_{f / d}$ and thus the real exchange rate in eq2 is more common among the world countries, we would adopt this version only in this thesis so that a decrease (increase) in the nominal and/or real exchange rate would mean an appreciation (depreciation) of the home currency.

\subsection{Purchasing Power Parity and Currency Undervaluation}

When we try to compare the domestic and foreign prices of a single commodity "' $\mathrm{i}$ " we expect that the Law of One Price (LOP) to hold provided that certain conditions such as negligible transportation costs do hold. Therefore, if LOP holds, then we can write as:

$$
\begin{array}{ll}
\frac{E_{d / f} P_{f}^{i}}{P_{d}^{i}}=1 \text { or } & \text { eq } 3 \\
P_{d}^{i}=E_{d / f} P_{f}^{i} & \text { eq } 4
\end{array}
$$

which states that the prices of commodity $i$ in the domestic and foreign country are the same when they are expressed in the same currency.

Absolute purchasing power parity (PPP) is the extension of this LOP to a basket of goods and services so that the prices are the average prices of the baskets. Thus eq 3 turns into:

$$
R E R=\frac{E_{d / f} P_{f}}{P_{d}}=1
$$

Which states that the baskets would cost the same amount in home and foreign countries when measured by the same currency. Absolute PPP would hold under several assumptions such as the baskets in foreign and home country include the same goods and services with the same weights; every product is tradable; there is no limitation for trade, transportation cost is negligible and so on.

Breakdown of most of these assumptions implies that the absolute PPP does not hold in reality. Nevertheless, an alternative version, relative PPP is considered a long-run equilibrium level for exchange rates. In relative PPP, the RER is equal to a constant number such as 2 but not equal to 1 :

$$
R E R=\frac{E_{d / f} P_{f}}{P_{d}}=\text { constant } \quad \text { eq } 6
$$

which indicates that the prices of the baskets would be a certain ratio of each other but not the same. If this is considered to be a long-run equilibrium level for the exchange rates, then a deviation from this equilibrium would lead to an undervaluation or an overvaluation of the currency. More specifically, if the home currency depreciates so that RER turn out to be higher than the long-run equilibrium constant, this would imply undervaluation of the domestic currency as well as higher relative prices for the foreign goods.

Relative PPP is more plausible provided that the price of non-tradable do not move differently in two different countries. However, one also needs to look at the changes in relative prices of the non-tradable in both countries before talking about the long-run equilibrium of exchange rates. If the relative price of nontradable is changing differently in different countries, it would be impossible to expect that the ratio of basket prices is non-changing constant, given that the baskets do include non-tradeable goods and services.

Let us now look at the study of Balassa-Samuelson in order to understand the effects of the price of nontradable on the long-run equilibrium of exchange rates, and thus on currency undervaluation.

\subsection{Price of Non-tradable and Real Exchange Rates}

The Balassa-Samuelson hypothesis relaxes the assumptions of identical production functions and factor price equalization. Therefore, the equality of non-traded good prices does not hold even in the long run. 
Moreover, the movement in the relative price of non-tradable is determined by the relative productivity growth in the tradable goods sector in each country. Relatively high productivity growth in the tradable leads to higher wages, and thus, to higher non-tradable good prices so that the result is an appreciated exchange rate (Asea and Corden, 1994).

\subsection{Balassa-Samuelson Effect}

In the Balassa-Samuelson model, the relative price of non-tradable, and thus, the real exchange rate movements, depends on the relative productivity growth rate in the traded and nontraded sectors.

In a small open economy, where the price of tables is fixed at world prices, higher productivity growth in the tradable sector leads to higher wages both in tradable and non-tradable sectors since the labor is mobile across the sectors. However, higher wages in the non-tradable, without a corresponding higher productivity in the sector, leads to higher relative prices for non-tradable. In turn, this leads to an appreciation of the real exchange rate.

Balassa-Samuelson effect then states that as countries achieve rapid productivity growth in tradable sectors, transitioning them from a lower-income to higher-income status, their prices of non-tradable increase and their currencies appreciate. Hence higher-income countries are expected to have more appreciated currencies.

The validity of Balassa-Samuelson (BS) theorem is investigated extensively in the international economics literature. One of the most distinguished papers on this issue is Canzoneri et al. (1999). The authors claim that the BS theorem is not always successful in explaining both short-term and long-term (20 years or longer) movements within the real exchange rate.

Similarly, studying pound sterling to dollar RER for even broader time horizons, Lothian and Taylor (2008) have concluded that the Balassa-Samuelson model is unsuccessful in explaining the RER movements except in the very long run. The authors show that forty percent of the movements in the real exchange rate is accounted for via the Balassa-Samuelson effect in a sample of one hundred eighty years. While the Balassa-Samuelson effect is tested in shorter time horizons ranging from one year to ten years, its effect is much smaller.

On the other hand, Berka and Devereux (2010) discover that the movements in the RER and the domestic relative prices of non-traded goods are extraordinarily correlated. Devereux et al. (2014) also study the Balassa-Samuelson effect for a set of European countries. They understood that productivity increases in the tradable sector relative to the non-tradable sector have a positive relationship with RER appreciations. Furthermore, Zhang (2017) finds that there is a positive link between a country's per capita income and its home price level.

Despite these mixed results on the validity of Balassa-Samuelson effects, we base our studies according to Rodrik (2008) and Berg and Maio (2010) which attempts to measure the currency undervaluation based on Balassa-Samuelson effects. Let us now look at these reference papers.

\subsection{Rodrik Model}

Rodrik (2008) is one of the pioneering works which has to look at the effects of currency undervaluation on economic growth. His conclusion is that currency undervaluation promotes the growth of developing countries, but not for developed countries.

Let's now review the models used in this study: RER is calculated as the nominal exchange rates (XART) is adjusted for the PPP conversion rates (PPP) from the Penn World Tables (PWT) as shown in the equation below where each country and each time are represented respectively with subscripts $i$ and $t$. 


$$
(R E R)_{i t}=\left(X R A T_{i t} / P P P_{i t}\right)
$$

Prices of non-tradable goods are lower in low-income countries according to Balassa-Samuelson theorem, Rodrik estimates a long-run equilibrium level of RER via the regression below:

$$
\ln (\widehat{R E R})_{l t}=\alpha_{0}+\alpha_{1} \ln (R G D P P C)_{i t}+f_{t}+e_{i t} \quad \text { eq } 8
$$

Above, RGDPPC is the per-capita real GDP from Penn World Tables, $\mathrm{ft}$ is the time fixed effect, and eit is the error term. RER undervaluation is calculated as the deviation of the observed RER and estimated one (eq 8).

$$
\text { Underval }_{i t}=\ln (R E R)_{i t}-\ln \left(\widehat{R E R}_{l t}\right.
$$

An index value bigger than 1 indicates a RER undervaluation.

Then, Rodrik used the following regression model initially to investigate the relationship between currency undervaluation and economic growth.

$$
\text { Growt }_{i t}=\gamma_{0}+\gamma_{1} \ln (\text { INIRGDPPC })_{i t}+\gamma_{2} \text { Underval }_{i t}+f_{t}+f_{i}+e_{i t} \quad \text { eq } 10
$$

Where $\mathrm{ft}$ is the time dummies, fi is country dummies, and where initial or the lag of real GDP per capita is used to capture the effects of convergence.

\section{Data}

This study uses panel data of 82 countries from the year 1990 to 2018. The data is periodic data of 6 sets of 5-years-period (for example 1990-1994, 1995-1999...). "Growth" is the percentage increase in real GDP and is directly obtained as a growth rate from the World Bank database. The growth rate is the average of growth rates of 5 years in each period.

"INIRGDPPC" is the first year real GDP per capita in each period. "Underval" is the currency undervaluation and is measured as highlighted in eq 9 where RER (real exchange rate) are obtained as directly from the World Bank databases. A growth rate is a percentage number and thus is not in the logarithmic form. INIRGDPPC and Underval, on the other hand, are used in natural logarithmic forms.

\section{Methodology, Results, and Discussions}

In this section, we present the highlights of the methodologies we used and give out the results of the tests and regression. Let us now start with the panel unit root tests.

\subsection{Panel Unit Root Tests}

There are several unit root tests that one can carry out to perform a panel unit root test. Levin-Lin-Chu (2002) is one of the panel unit root test that was built on the premise that all observations have a homogenous level of integration. Maddala and Wu (1999), on the other hand, came up with the various specification of panel unit root test, where they employed distinct panel unit root processes. A similar test was created by Im, K., Pesaran, M. H., \& Shin, Y. (2001) (IPS), while Hadri, K. (2000) suggested a different hypothesis. Hadri carried out the stationarity of the panel observations against the existence of a unit root. In Table 1, we present the unit test results based on three different methods: i) Im-Pesaran-Shin (IPS); ii) Levin-Lee-Chu (2002) (LLC) and iii) Augmented Dickey Fuller-Fisher (ADF-Fisher) tests. While IPS and ADF-Fisher tests assume individual unit root processes, LLC assumes identical (common) unit root processes across the cross-sections. All three tests have a null hypothesis that there exists a unit root according to $\mathrm{ADF}$ specification (equation 11):

$$
\Delta y_{i t}=\alpha y_{i t-1}+\sum \beta_{i j} \Delta y_{i t-j}+X_{i t} \delta+v_{i t} \quad \text { eq } 11
$$


Where $y_{i t}$ presents the pooled variable, $X_{\text {it }}$ presents exogenous variables in the model, and yit presents the error terms which are assumed to be mutually independent disturbances. The IPS test estimates a separate ADF regression for each of the three cross-sections to allow for individual unit root processes.

Table 1: Panel Data Unit Root Test

\begin{tabular}{|c|c|c|c|}
\hline Variable & $\begin{array}{c}\text { IPS } \\
\text { Test Statistics } \\
(\mathrm{P}-\text { Value })\end{array}$ & $\begin{array}{c}\text { LLC } \\
\text { Test Statistics } \\
(\mathrm{P}-\text { Value })\end{array}$ & $\begin{array}{c}\text { ADF-Fisher } \\
\text { Test Statistics } \\
(\mathrm{P}-\text { Value })\end{array}$ \\
\hline Growth & $-0.13(0.450)$ & $14.76(1.000)$ & $264.7(0.000)^{*}$ \\
\hline RGDPPC & $0.09(1.000)$ & $-2.37(0.010)^{*}$ & $116.6(0.992)$ \\
\hline Underval & $-1.29(0.052)$ & $3.44(0.991)$ & $155.08(0.293)$ \\
\hline
\end{tabular}

Source: Author's computation. Note1: (*), (**) and (***) indicate that the estimated parameters are significant at the 1\%, 5\%, and 10\% significance level respectively. Note 2: Null hypothesis is that there exists unit root.

Table 1 presents the results of the panel unit root test at level data. Majority of the test results fail to reject the null hypothesis for all their variables, thus providing evidence for the non-stationarity of the level data. That is, the variables were found to be non-stationary at levels.

\subsection{The Panel Co-integration Test}

In order to investigate if a co-integration relationship exists between the variables, we employ the techniques presented by Pedroni (1999). The Pedroni cointegration test is presented in equation 12:

$$
y_{i t}=a_{i}+\delta_{i t}+\beta_{1 i} X_{1 i, t}+\beta_{2 i} X_{2 i, t}+\cdots+\beta_{m i} X_{m i, t}+\varepsilon_{i t} \quad \text { eq } 12
$$

For $\mathrm{t}=1, \ldots, \mathrm{T}, \mathrm{i}=1, \ldots, \mathrm{N}$, and $\mathrm{m}=1, \ldots, \mathrm{M}$.

Where $\mathrm{T}$ presents the number of observations, $\mathrm{N}$ presents the number of individual members in the panel, and $\mathrm{M}$ presents the number of regression variables. The structure of the estimated residual is expressed in equation 13:

$$
\varepsilon_{i t}=\psi_{i} \varepsilon_{i t-1}+v_{i t}
$$

eq 13

where $\psi_{i}$ is the autoregressive coefficient of the residual $\varepsilon_{i t}$ from Equation 12.

This method uses four-panel statistics (within-dimension) and three group statistics (between dimensions) for its hypotheses testing. Failing to reject the null hypothesis indicates no co-integration between the variable against its alternative hypothesis of the presence of co-integration. For the four-panel statistics, the AR1 is the same (common) across sections, while in the group statistics, the AR coefficient is permitted to change across sections. Rejection of the null hypothesis based on panel statistics implies that the variables are cointegrated for all observations. However, rejection of the null hypothesis based on group statistics implies that co-integration between the variables only exist for probably one observation. For the cointegration analysis, 3 lags were chosen based on VAR Lag Order Selection Criteria. In Table 2, looking at the statistics, we can conclude that, the variables are co-integrated for all observations, as we reject the null hypothesis of no co-integration relationship based on Phillip-Perron (PP) and Augmented Dickey-Fuller (ADF) statistics.

Table 2: Panel Co-integration Test

\begin{tabular}{|c|c|c|c|}
\hline & \multirow{2}{*}{ Panel } & Statistics & \multirow{2}{*}{ Group } \\
\cline { 3 - 4 } & -0.4435 & Weighted & \\
\hline Variance ratio & 1.2192 & -5.3766 & 5.5781 \\
\hline RHO & & -0.3149 & \\
\hline
\end{tabular}




\begin{tabular}{|c|c|c|c|}
\hline PP & $\left(-6.3365^{*}\right)$ & $\left(-17.3329^{*}\right)$ & $\left(-14.4241^{*}\right)$ \\
\hline ADF & $\left(-6.0665^{*}\right)$ & $\left(-14.038^{*}\right)$ & $\left(-13.1732^{*}\right)$ \\
\hline
\end{tabular}

Source: Author's computation. Note1: $(*),(* *)$ and $(* * *)$ indicate that the estimated parameters are significant at the $1 \%, 5 \%$, and $10 \%$ significance level respectively.

These results bring about the application of the FMOLS and DOLS techniques. They require variable to be in a non-stationary state at levels. Since this satisfies the condition to evaluate long-run relationships between variables, it becomes expedient to carry out panel co-integration technique to evaluate whether there is a long-run equilibrium relationship among the non-stationary observations in their level forms.

\subsection{Panel FMOLS and DOLS Models}

Once a co-integration relationship has been found, the use of Pooled Least Square (PLS) techniques would become problematic.

Since at that point, the use of PLS can easily lead to biased estimations, which is as a result of endogeneity and serial correlation problem. Panel FMOLS and DOLS techniques have been found efficient method to remove these problems. DOLS is a parametric technique that is mostly used to acquire long - run coefficient of the parameter estimate by taking into account the lagged and the lead values of the variables. FMOLS, on the other hand, is a technique used in removing autocorrelation impact by employing a non-parametric transformation to the model residuals obtained from the co-integration regression.

Panel DOLS estimator is constructed as follows:

$$
y_{i t}=\beta_{i} X_{i t}+\sum_{K=-P i}^{P i} \gamma_{i k} \Delta X_{i t-k}+\varepsilon_{i t} \quad \text { eq } 14
$$

Where $\mathrm{P} i$ and $-\mathrm{P} i$ are lagged and lead values. It assumes that there is no dependence relationship between cross-sections according to this model. $\beta_{i}$ is DOLS estimator according to equation 15:

$$
\beta_{i}^{*}=N^{-1} \sum_{i=1}^{N}\left(\sum_{t=1}^{T} Z_{i t} Z^{\prime}{ }_{i t}\right)^{-1}\left(\sum_{t=1}^{T} Z_{i t} Y_{i t}^{*}\right) \quad \text { eq } 15
$$

where, $Z_{i t}=\left(X_{i t}-X_{i}, \Delta X_{i t-p}, \ldots, \Delta X_{i t+p}\right)$ is the vector of regressors. The group-mean panel DOLS estimator is estimated by obtaining an arithmetic mean of cointegration coefficients and is expressed in equation 16:

$$
\hat{\beta}=N^{-1} \sum_{i=1}^{N} \hat{\beta}_{i} \quad \text { eq } 16
$$

$\hat{\beta}_{i}$ is the estimated coefficient acquired from DOLS for each cross-section? Group-mean panel DOLS tstatistic is estimated in equation 17:

$$
t_{\widehat{\beta}}=N^{-1 / 2} \sum_{i=1}^{N} t_{\widehat{\beta}} \quad \text { eq } 17
$$

$\hat{\beta}_{i}$ is t-statistic of each coefficient obtained from DOLS for each cross-section.

Panel FMOLS estimator is constructed as follows:

$$
\begin{array}{ll}
Y_{i t}=\alpha_{i}+\beta X_{i t}+e_{i t} & \text { eq } 18 \\
X_{i t}=X_{i t-1}+\varepsilon_{i t} & \text { eq } 19
\end{array}
$$

Where e and $\varepsilon$ are error terms with stationary. The panel FMOLS estimator for $\beta$ estimator can be expressed in equation 20 :

where

$$
\begin{array}{ll}
\beta_{N T}^{*}=N^{-1} \sum_{t=1}^{N}\left(\sum_{t=1}^{T}\left(X_{i t}-\bar{X}_{i}\right)^{2}\right)^{-1}\left(\sum_{t=1}^{T}\left(X_{i t}-\bar{X}_{i}\right)^{2} Y_{i t}^{*}-T \hat{\tau}_{i}\right) & \text { eq } 20 \\
Y_{i t}^{*}=\left(Y_{i t}-\bar{Y}_{i}\right)-\frac{\widehat{L}_{21 i}}{\hat{L}_{22 i}} \Delta X_{i t} & \text { eq } 21
\end{array}
$$

$$
\hat{\tau}_{i}=\hat{\Gamma}_{21 i}+\Omega_{21 i}^{0}-\frac{\hat{L}_{21 i}}{\hat{L}_{22 i}}\left(\hat{\Gamma}_{22 i}-\Omega_{22 i}^{0}\right) \quad \text { eq } 22
$$

where $\Omega_{i}=\Omega^{0}{ }_{i}+\Gamma_{i}+\Gamma^{\prime}{ }_{i}$ express long-run covariance matrix where $\Omega^{0}{ }_{i}$ is the contemporary covariance and $\Gamma_{i}$ is a weighted sum of covariances. $L_{i}$ is lower triangular in the decomposition of $\Omega_{i}$. 
FMOLS and DOLS methods make it easy to use regression analysis, without establishing the first difference of the co-integrated variables. Therefore, analysis can be carried out without losing any information regarding the dependent and independent variables.

In this section, we report the estimation results from using both the Fully Modified Ordinary Least Square (FMOLS) and Dynamic Ordinary Least Square (DOLS). Our focus here is the effect of currency undervaluation on the changes in economic growth rates across countries.

Table 3: Panel Estimation Results.

\begin{tabular}{|c|c|c|}
\hline \multicolumn{3}{|c|}{ Growth = f ( Real GDP per capita, Undervaluation) } \\
\hline DOLS & FMOLS \\
\hline Ln(INIGDPPC) & -0.32329 & -0.1029 \\
& $\left(-15.782^{*}\right)$ & $\left(-2.834^{*}\right)$ \\
\hline Ln(Underval) & 0.4492 & 0.1488 \\
& $\left(8.306^{*}\right)$ & $(1.382)$ \\
\hline
\end{tabular}

Source: Author's computation. Note1: the number in parenthesis are t-statistics. Note2: $(*),(* *)$ and $(* * *)$ indicate that the estimated parameters are significant at the $1 \%, 5 \%$, and $10 \%$ significance level respectively.

Table 3 present the FMOLS and DOLS estimation results according to Balassa-Samuelson. The panel estimation using the FMOLS and the DOLS was justified, based on the fact that the level data observations have unit root process. DOLS results are reported in the first column, while the FMOLS results are reported in the second column.

DOLS results show that both initial GDP per capita and the currency undervaluation variables are of the correct sign and statistically significant at $1 \%$ significance level. Initial GDP per capita has a negative coefficient following convergence theory, which implies that countries with initially high GDP per capita have a lower economic growth rate.

On the other hand, currency undervaluation has a positive coefficient, implying that undervaluation currencies help boost economic growth. In fact, results show that $1 \%$ increase in undervaluation leads to $0.44 \%$ increase in growth rates. Table 3 also shows that FMOLS results are not as strong as DOLS results are. In FMOLS results, the coefficient of "Underval" is not statistically significant at all while the coefficient of initial GDP per capita is statistically significant at 5\% and of correct sign.

The results presented in Table 3 show that the coefficient estimate of currency undervaluation based on FMOLS is statistically insignificant. This convinced us to rerun the same regressions by using an alternative measurement of the real exchange rate, and thus, an alternative measurement of currency undervaluation. We did this still based on the reference work of Rodrik (2008). In that study, Rodrik tried to eliminate any biases due to the fact that the Balassa-Samuelson effect involves adjustments based on factors affecting both price levels and GDP per capita. The alternative measurement of the real exchange rate is calculated as

$$
R E R=\frac{X R A T}{C P I} \quad \text { eq } 23
$$

Where XRAT is the nominal exchange rate, and the CPI is the consumer price index. Undervaluation is measured as before in Equation 9 but by using the new RER series.

Table 4 below presents results based on this alternative measurement of currency undervaluation.

Table 4: Panel Estimation Results (Alternative Undervaluation measurement).

\begin{tabular}{|c|c|c|}
\hline \multicolumn{3}{|c|}{ Growth = f ( Real GDP per capita, Undervaluation) } \\
\hline DOLS & FMOLS \\
\hline Ln(INIGDPPC) & -0.1036 & -0.1177 \\
& $\left(-8.034^{*}\right)$ & $\left(-8.026^{*}\right)$ \\
\hline Ln(Underval) & 0.5073 & 0.1824 \\
& $\left(2.0582^{*}\right)$ & $(7.0932 *)$ \\
\hline
\end{tabular}

Source: Author's computation Note1: the number in parenthesis are t-statistics. Note2: $(*),(* *)$ and $(* * *)$ indicate that the estimated parameters are significant at the $1 \%, 5 \%$, and $10 \%$ significance level respectively. 
The results in Table 4 show that the coefficient estimate for initial GDP per capita (and hence for convergence) is statistically significant at $1 \%$ significance level and of correct sign under both DOLS and FMOLS estimations, while the currency undervaluation is of correct sign and statistically significant at 5\% significance level under DOLS and 1\% significance level under FMOLS estimation.

More specially FMOLS coefficient estimate for Undervaluation is 0.1824 with a t-statistics of 7.09, which shows that $1 \%$ increase in currency undervaluation leads to $0.18 \%$ increase in GDP growth rates. This shows an improvement over the results presented in Table 3. Moreover, from DOLS results in Table 4, we can infer that 1 percent undervaluation would boost growth by 0.50 percent point.

DOLS and FMOLS estimation results presented in Table 3 and 4 show us that currency undervaluation has a positive effect on GDP growth rates. This result is in line with our reference paper Rodrik (2008) and many others in the literature.

In the final section of this chapter, we would like to investigate if this result depends on the selection of countries. More specifically, we want to know if the positive impact of currency undervaluation on GDP growth rates are valid for the samples of developed countries only and developing countries only separately. To carry out this work, we divide our panel data into 2 sub-sets: (1) developed countries only and (2) developing countries only. We did this by using the categorization based on the definitions used in the works of the United Nations.

Table 5 presents the FMOLS and DOLS estimation results for developed and developing countries separately. For developing countries, the results are supportive of the theoretical expectations. In other words, the coefficient estimates for Ln (INIGDPPC) and Ln (Underval) are both statistically significant at $1 \%$ significance level and of correct sign, based on both DOLS and FMOLS estimations. Moreover, the coefficient estimates for currency undervaluation are greater compared to the ones presented in Tables 3 and 4 , indicating that currency undervaluation may play a more prominent role in boosting GDP growth rates for developing countries.

On the other hand, results for currency undervaluation in developed-countries-only are statistically insignificant under both FMOLS and DOLS estimation. This is also a well-documented phenomenon in the literature and definitely in our reference article Rodrik (2008).

Table 5: Panel Regression Results (Developing and Developed Countries Separately)

\begin{tabular}{|c|c|c|c|c|}
\hline Independent variables & \multicolumn{2}{|c|}{ Developing countries } & \multicolumn{2}{c|}{ Developed countries } \\
\hline & DOLS & FMOLS & DOLS & FMOLS \\
\hline Ln (INIGDPPC) & -0.3823 & -0.1938 & -0.09315 & -0.0307 \\
& $(-14.384 *)$ & $(-7.997 *)$ & $\left(-8.7165^{*}\right)$ & $(-0.1015)$ \\
\hline Ln (Underval) & 0.6733 & 0.2466 & -0.4476 & -0.8056 \\
& $9.992^{*}$ & $4.229^{*}$ & $(-0.5965)$ & $(-0.6251)$ \\
\hline
\end{tabular}

Source: Author's computation. Note1: The numbers in parenthesis are t-statistics. Note2: $(*),(* *)$ and $(* * *)$ indicate that the estimated parameters are significant at the $1 \%, 5 \%$, and $10 \%$ significance level respectively. Observations are average for 5 years period. All regressions include FMOLS and DOLS.

Economic growth, as seen above for the developing economies over a long time, using the DOLS and FMOLS tends to increase with the currency undervaluation and decrease with the initial real GDP per capita. For the developed economies with respect to undervaluation, this is not the case. As said earlier, the coefficient estimates for the currency undervaluation are statistically insignificant even at $10 \%$ significance level. Most crucial for this study, the estimated coefficient on the undervaluation of developing countries is highly statistically significant both for the DOLS and FMOLS. This comforting and interesting results affirmed Rodrik (2008) that undervaluation would enhance economic growth in the developing countries rather than in the developed countries.

\section{Conclusions}

The concept and impact of the real exchange rate are important and mostly felt especially in open economies. These are economy that embarks on exportation and importation of goods and service. Since economic growth is usually measured by the monetary value of output produced in an economy, the impact of the exchange rate would be enormous on their level of growth. The basic point of this study can be briefly 
stated. In developing countries, tradable economic activities are perceived as crucial and special. Tradable economic are goods and services which are either exportable or importable.

Though these tradable activities lack the market and institutional failures that mostly keep developing countries poor. Persistent depreciation of currency enhances the relative profitability of tradable investment and on the other hand, curb or reduce the economic cost of these distortions. This is one way or another accelerate the process of structural change in a manner that stimulates growth. This is one underlying reason why the adventure of undervaluation is highly related to speedy economic growth. The estimated coefficient for developing countries is plausible. The implication of this is that enhancing undervaluation can boost economic growth rate.

\section{List of abbreviations:}

ADF: Augmented Dickey-Fuller

BS: Balassa-Samuelson

DOLS: Dynamic Ordinary List Square

FMOLS: Fully Modified Ordinary Least Square

INIGDPPC: Initial Real GDP Per Capita

IPS: Im-Pesaran-Shin

LLC: Levin-Lee-Chu

PP: Phillip-Perron

RER: Real Exchange Rate

RGDPPC: Real GDP Per Capita

UNDERVAL: Real Exchange Rate Undervaluation

\section{Declarations:}

* Availability of data and material: Data are available on the World Bank database.

* Competing interests: There are no competing interests in relation to this work mentioned in this paper.

* Funding: There is no funding for this paper.

* Authors' contributions: All authors contributed to the design of the study, data collection, data analysis and development of the manuscript.

* Acknowledgements: The authors would like to thank the journal of Economic Structures, and Near East university for research time.

* Authors' information:

1- Mehdi Seraj: (Corresponding author, Economics PhD, Near East University, Address: Department of Economics, Near East University, Nicosia, North Cyprus, Mersin 10, Turkey, Email:

mehdi.seraj@neu.edu.tr, Tel: +905338731432)

2- Cagay Coskuner: (Assoc. Prof. of Economics, Eastern Mediterranean University, Famagusta, North Cyprus, Mersin 10, Turkey)

3- Seyi Saint Akadiri: (Economics PhD, Central Bank of Nigeria)

4- Negar Bahadori: (Master of Business Administration, Eastern Mediterranean University, North

Cyprus, Mersin 10, Turkey) 


\section{References:}

Béreau, S., Villavicencio, A. L., \& Mignon, V. (2012). Currency misalignments and growth: a new look using nonlinear panel data methods. Applied Economics, 44(27), 3503-3511.

Cheung, Y. W., Chinn, M. D., \& Fujii, E. (2007). The overvaluation of renminbi undervaluation. Journal of International Money and Finance, 26(5), 762-785.

Das, D. K. (2009). The evolution of renminbi yuan and the protracted debate on its undervaluation: An integrated review. Journal of Asian Economics, 20(5), 570-579.

Elbadawi, I., Kaltani, L., \& Soto, R. (2009). Aid, real exchange rate misalignment and economic performance in sub-Saharan Africa.

Gala, P. (2007). Real exchange rate levels and economic development: theoretical analysis and econometric evidence. Cambridge Journal of economics, 32(2), 273-288.

Gluzmann, P. A., Levy-Yeyati, E., \& Sturzenegger, F. (2012). Exchange rate undervaluation and economic growth: Diaz Alejandro (1965) revisited. Journal of Economics Letters, 117, 666-672.

Haddad, M., \& Pancaro, C. (2010). Can real exchange rate undervaluation boost exports and growth in developing countries? Yes, but not for long.

Hadri, K. (2000). Testing for stationarity in heterogeneous panel data. The Econometrics Journal, Vol 3, $148-161$.

Im, K., Pesaran, M. H., \& Shin, Y. (2003). Testing for Unit Roots in Heterogeneous Panels. Journal of Econometrics, Vol 115, 53-74.

Korinek, A., \& Servén, L. (2010). Real exchange rate undervaluation: static losses, dynamic gains. World Bank Policy Research Working Paper, 5250.

Levin, A., Lin, C., \& Chu, C. (2002). Unit root tests in panel data: asymptotic and finite-sample properties. Journal of Econometrics, Vol 108, 1-24.

Levy-Yeyati, E., \& Sturzenegger, F. (2007). Fear of floating in reverse: exchange rate policy in the 2000s. In LAMES-LACEA Annual Meetings.

Maddala, G. S., \& Wu, S. (1999). A Comparative Study of Unit Root Tests with Panel Data and a New Simple Test. Oxford Bulletin of Economics and Statistics, Vol 61, 631-652.

Magud, N., \& Sosa, S. (2013). When and why worry about real exchange rate appreciation? The missing link between Dutch disease and growth. Journal of International Commerce, Economics and Policy, 4(02), 1350009.

Mbaye, S. (2013). Currency undervaluation and growth: Is there a productivity channel?. International Economics, 133, 8-28.

Mejía-Reyes, P., Osborn, D. R., \& Sensier, M. (2010). Modelling real exchange rate effects on output performance in Latin America. Applied Economics, 42(19), 2491-2503.

Nouira, R., \& Sekkat, K. (2012). Desperately seeking the positive impact of undervaluation on growth. Journal of Macroeconomics, 34(2), 537-552.

Papanikos, G. T. (2015). The real exchange rate of euro and Greek economic growth. The Journal of Economic Asymmetries, 12(2), 100-109. 
Pedroni, P. (1999). Critical Values for Cointegration Tests in Heterogeneous Panels with Multiple Regressors. Oxford Bulletin of Economics and Statistics, Vol 61, 653-670.

Razmi, A., Rapetti, M., \& Skott, P. (2012). The real exchange rate and economic development. Structural Change and Economic Dynamics, 23(2), 151-169.

Rodrik, D. (2008). The real exchange rate and economic growth. Brookings papers on economic activity, 2008(2), 365-412.

Tang, B. (2015). Real exchange rate and economic growth in China: A cointegrated VAR approach. China Economic Review, 34, 293-310.

Vaz, P. H., \& Baer, W. (2014). Real exchange rate and manufacturing growth in Latin America. Latin American Economic Review, 23(1), 2. 